\title{
PEMANFAATAN INTERNET PADA SMARTPHONE DALAM MENDUKUNG KEGIATAN BISNIS ONLINE DI LINGKUNGAN ARISAN RT
}

\author{
Hafni Hafsah', Zulafwan'2, Willyansah ${ }^{3}$ \\ ${ }^{123}$ Amik Tri Dharma, Pekanbaru, Indonesia \\ Jl. Soekarno - Hatta No.99, Labuh Baru Bar., Kec. Payung Sekaki, Kota Pekanbaru, Riau 28292 \\ email (hafnihafsah@amiktridharmpku.ac.id ${ }^{1}$, zulafwan@amiktridharmapku.ac.id ${ }^{2}$, \\ willyansah@amiktridharmapku.ac.id ${ }^{3}$ )
}

\begin{abstract}
Abstrak: Pengabdian kepada masyarakat yang dilakukan dan ditulisakan dalam artikel ini terkait dengan pemanfaatan teknologi informasi dan komunikasi melalui penggunaan internet pada smartphone oleh ibu-ibu anggota arisan di lingkungan Rukun Tetangga 01, Perumahan Delima Puri. Pekanbaru, Riau. Kegiatan ini dilakukan melalui seminar dengan menyampaikan materi terkait pemanfaatan internet dalam mendukung jual beli online dan sekaligus untuk mengenalkan istilah umum bahasa inggris pada jual beli online. Tulisan ini bersifat deskriftif yang dimaksudkan untuk memperoleh informasi pemahaman dan permasalahan ibu -ibu anggota arisan terkait materi yang diangkat dalam seminar. Pada era modern saat ini, teknologi informasi dan komunikasi (TIK) memiliki peran yang sangat penting dalam meningkatkan dan mengembangkan perekonomian masyarakat, khususnya dengan pemberdayaan perempuan yaitu dalam hal ini ibu-ibu anggota arisan. Kegiatan ini juga dimaksudkan untuk berbagi ilmu tentang pemanfaatan internet melalui pemanfaatan smartphone guna mendukung kegiatan usaha online dan mengenalkan istilah-istilah Bahasa Inggris yang umum digunakan dalam hal jual beli online melalui internet. Selain hal tersebut di atas, seminar ini dapat mengisi kegiatan arisan ibu-ibu RT disamping kegiatan pertemuan rutin yang mereka lakukan, yang diharapkan dapat meningkatkan pemahaman mereka dalam hal pemanfaatan internet. Secara umum, ibu-ibu tersebut tidak mengalami kendala yang cukup berarti terkait pemahaman materi yang diberikan. Namun pada ibu-ibu anggota yang usianya di atas 50 tahun, penggunaan internet lebih kepada alat untuk berkomunikasi saja. Sementara itu, jenis platform terbanyak yang digunakan dalam beberapa usaha online yang mereka lakukan adalah aplikasi WhatsApp.
\end{abstract}

\section{Kata Kunci: Smartphone, Internet, Business online}

\begin{abstract}
The writers wrote this article based on the activity implemented as a part of community service. It related to the use of information and communication technology ICT) through the internet on the smartphone by female members of social gathering within the neighborhood of Delima Puri Housing Compound of Pekanbaru city, Province of Riau. The activity was carried out in a seminar by presenting materials related to internet use in terms of supporting online business as well as introducing common buying and selling terms in English. The paper used the descriptive method which was intended to obtain information on the understanding and problems of the members related to the material raised in the seminar. In today's modern era, information and communication technology (ICT) has a very important role in improving and developing the community's economy, particularly by empowering women. This activity was also intended to share the writers' knowledge about the use of the internet through smartphones and the English terms that are commonly used in terms of buying and selling online via the internet. In addition to the aforementioned, this seminar was an additional agenda despite their routine meeting every month, expected to increase their understanding of internet use. In general, they did not experience significant obstacles related to the understanding of the material provided. However, among members who are over 50 years old, the use of the internet is more of a communication tool. Meanwhile, the most common type of platform used in some of their online businesses is the WhatsApp application.
\end{abstract}

Keywords: Smartphone, Internet, Business Online 


\section{Pendahuluan}

Pengabdian kepada masyarakat merupakan salah satu kegiatan yang harus dilaksanakan oleh seorang Dosen dalam menunjang Tri Dharma Perguruan Tinggi. Kegiatan pengabdian ini adalah merupakan suatu bentuk tugas bagi Dosen dalam melakukan transfer ilmu dan pengetahuan kepada masyarakat, ataupun mengangkat permasalahan yang ada dalam masyarakat atau kelompok masyarakat dengan mencari pemecahan terhadap permasalahan tersebut sehingga memberikan manfaat bagi masyarakat tersebut.

Pengabdian kepada masyarakat yang dilakukan dan ditulisakan dalam artikel ini terkait dengan pemanfaatan teknologi informasi dan komunikasi melalui penggunaan internet pada smartphone. Pada era modern saat ini, teknologi informasi dan komunikasi (TIK) memiliki peran yang sangat penting dalam meningkatkan dan mengembangkan perekonomian masyarakat. Kemajuan TIK memberikan kesempatan kepada semua pihak untuk bisa saling berbagi informasi dan pengetahuan, membuka peluang pembangunan di sektor perekonomian serta meningkatkan interaksi sosial kearah yang lebih maju melalui teknologi yang ditawarkannya (Melhem, dkk., 2009).

Salah satu penggunaan internet dalam mendukung perekonomian masyarakat adalah dalam sistem jual beli secara online yang telah tumbuh dengan pesat dan menjadi salah satu cara yang bisa digunakan dalam meningkatkan pengembangan dan pemberdayaan masyarakat.

Namun demikian, terdapat beberapa faktor yang membatasi pemanfaaatan teknologi informasi dan komunikasi (TIK) baik teknis, sosial maupun budaya sebagai sarana pengembangan dan pemberdayaan bagi masyarakat, khususnya dalam hal ini perempuan. Hambatan yang sering juga dihadapi oleh masyarakat yaitu masalah terbatasnya ketersediaan waktu dan biaya.

Sementara itu, terkait faktor- faktor yang menjadi penghambat kurang berkembangnya penggunaan Teknologi Informasi di kalangan wanita yang memiliki usaha skala kecil atau rumah tangga menurut Lestari (2010) yaitu minimnya informasi tentang TI, rendahnya kesempatan dan akses wanita dalam mendapatkan pendidikan dan pelatihan terkait dengan TI dan kendala sosio kultural yang masih melihat wanita dirasa kurang mampu bekerja di ranah teknologi serta masih dipandang lebih baik melakukan pekerjaan rumah tangga. Meski sebenarnya, tidak ada masalah menjadi ibu rumah tangga. Namun apabila memiliki keterampilan dalam membuat produk/jasa yang bisa dipasarkan secara online akan menambah pendapatan bagi keluarga.

Penggunaan internet untuk mengakses media sosial oleh kaum perempuan di Indonesia mencapai 79,92\%, mengakses informasi atau berita dengan porsi $64,06 \%$, hiburan $41,86 \%$, mengerjakan tugas $28,5 \%$, dan surat elektronik 20,41\%, dimana data ini disampaikan oleh Kepala Seksi Statistis Kemiskinan, BPS, Nur Syahrizal dalam bisnis.com (2018).

(Nurhadi, 2010: 1) menyatakan bahwa pada awalnya mayoritas ibu RT masih mengutamakan peran sebagai ibu rumah tangga, sehingga hampir seluruh waktunya digunakan untuk mengurus keluarga sehingga kurang mengetahui perkembangan teknologi yang ada. Selain hal tersebut juga disebabkan tingkat pendidikan dan 
keterampilan yang rendah, biaya akses internet, pengggunaan bahasa yang relatif didominasi oleh bahasa asing (dalam hal ini adalah Bahasa Inggris) dalam teknologi juga merupakan suatu hambatan yang nyata. Namun Saat ini, banyak para perempuan yang sudah mulai menyadari pentingnya peran TI dalam meningkatkan efisiensi dan efektivitas kinerja, baik dalam pekerjaan atau bisnis.

Pemberdayaan perempuan sudah memasuki era pemanfaatan teknologi informasi. Penggunaan teknologi informasi membantu perempuan di beberapa bidang seperti perdagangan dan kewirausahaan sebagai sumber informasi dan sarana untuk mempromosikan dan memasarkan produk.

Di negara berkembang seperti Indonesia, pengguna internet oleh perempuan terutamanya ibu rumah tangga dapat mendukung perekonomian keluarga untuk mendapatkan tambahan pendapatan melalui jual beli online, terutama saat terjadinya pandemic covid 19, ataupun dengan kegiatan ini dapat mensiasati sumber pendapatan dimana kemungkinan kepala keluarga kehilangan pekerjaan.

Sejalan dengan tujuan dari kegiatan ini yang dilatarbelakangi dengan semakin berkembangnya teknnologi di bidang internet melalui penggunaan smartphone yang pemanfaatannya masih belum maksimal digunakan dalam kegiatan-kegiatan atau yang mendukung usaha bagi masyarakat, khususnya ibu-ibu rumahtangga. Oleh karena itu, kegiatan pengabdian ini dimaksudkan untuk mengenalkan internet sebagai media yang dapat digunakan dalam kegiatan jual beli online untuk mendukung usaha yang dilakukan oleh ibu-ibu arisan sebagai kelompok masyarakat. Kemudian, mengenalkan istilah-istilah Bahasa Inggris yang digunakan dalam jual beli online yang belum difahami atau diketahui oleh ibu-ibu arisan khususnya bagi ibu -ibu di lingkungan Rukun Tetangga.

\section{Tinjauan Pustaka}

\section{Smartphone}

Smartphone atau ponsel cerdas adalah perangkat pintar yang digunakan sebagai alat untuk berkomunikasi. Ponsel cerdas tidak hanya digunakan sebagai alat berkomunikasi biasa, tetapi di dalamnya terdapat fitur-fitur lain seperti pengirimian email, permainan, media sosial dan sebagainya. Apabila dibandingkan dengan telepon genggam biasa, smartphone jelas lebih unggul, karena memiliki teknologi layar sentuh dan memiliki tampilan fitur-fitur yang menarik dan beberapa jenis memiliki fungsi yang hampir sama dengan komputer/laptop.

Ponsel cerdas pertama dirancang oleh perusahaan komputer IBM pada tahun 1992 dan dipamerkan pertama kali di Las Vegas, Nevada, Amerika Serikat. Kemudian pada tahun 1993 dipasarkan ke publik.

Smartphone merupakan perangkat elektronik yang hampir dimiliki oleh setiap orang di berbagai belahan dunia, kemampuan lebih dari sekedar fungsi panggilan dan SMS pengiriman pesan pendek) menjadikan banyak produsen berlomba-lomba membuat teknologi yang canggih untuk membuat produk mereka laris (Djunu, 2016). 
Handphone/ smartphone atau telepon genggam adalah alat komunikasi yang selalu berkembang dan banyak digunakan oleh kalangan manapun. Hal senada lebih lanjut disampaikan oleh Kepala Seksi Statistis Kemiskinan, BPS, Nur Syahrizal dalam bisnis.com (2018) bahwa ponsel menjadi media yang paling banyak digunakan untuk mengakses internet di Indonesia, yakni mencapai 91,67\%. Sementara itu, laptop sebanyak 22,91\% dan komputer $16,96 \%$. Kemudian, rata-rata, sebanyak 68,59\% perempuan Indonesia menggunakan ponsel, dengan perincian $74,73 \%$ di perdesaan dan $61,63 \%$ di perkotaan.

Jumlah dan jenis smartphone saat ini semakin banyak dan bahkan nama produknya juga bermacam-macam. Smartphone memiliki tiga macam sistem operasi (operating system), yaitu:

a. iOS,

Sistem operasi ini dibuat oleh perusahaan Apple Amerika, dan selama beberapa generasi Apple adalah penyedia perangkat yang memiliki kualitas tinggi dengan harga yang juga berada di atas. Selain digunakan pada smartphone, sistem operasi ini juga dapat digunakan pada komputer laptop.

\section{b. Android}

Android pertama kali digunakan pada produk Samsung dan diciptakan oleh Andy Rubin. Sistem operasi Android adalah sistem yang cepat perkembangannya (karena penggunaan system ini banyak digunakan pada smartphone lainnya yang muncul berikutnya, karena system operasi ini memberikan pilihan yang beragam dalam urusan bisnis, hiburan, game dsb. (Android.com) terdapat lebih dari 24.000 ponsel dan tablet yang menjalankan sistem operasi android)

\section{c. Windows}

Windows adalah sistem operasi yang digunakan untuk data center atau server. Sistem operasi ini merupakan system bawaan yang biasanya diterapkan pada komputer atau laptop.

Windows diciptakan oleh perusahaan komputer software Microsoft Amerika, namun kemudian perusahaan telepon genggam Nokia adalah perusahaan yang mengalikasikan sistem ini pada jenis handphone.

\section{d. Internet}

Internet atau Interconnection- networking adalah sebuah jaringan komputer global, yang terdiri dari jutaan computer yang saling terhubung dengan menggunakan protocol yang sama untuk berbagi informasi secara bersama. Internet merupakan kumpulan atau penggabungan jaringan computer lokal atau LAN menjadi jaringan computer global atau WAN. Jaringan tersebut saling berhubungan atau berkomunikai satu sama lain dengan berbasis protokol IP (internet protocol) dan TCP (transmission Control Protocol) atau UDP (User Datagram Protocol) sehingga setiap penggunan pada setiap jaringan dapat mengakses semua layanan yang disediakan oleh setiap jaringan. Dengan 
menggunakan protokol tersebut arsitektur jaringan computer yang berbeda akan dapat saling mengenli dan bisa berkomunikasi (Aji Supriyanto2005 :336).

Internet adalah salah satu kebutuhan penting bagi manusia pada zaman modern ini. Penggunaan internet memudahkan banyak sektor kehidupan, terutama dalam bidang komunikasi. Dengan internet, dapat berkomunikasi tanpa batas ruang dan waktu.

Negara Indonesia yang merupakan salah satu pasar yang menjanjikan untuk teknologi ini dimana jumlah penduduknya cukup besar, yaitu sebanyak 274,9 juta jiwa berdasarkan data dari datareportal.com. Sekitar $49,7 \%$ diantara penduduk Indonesia adalah perempuan dan 50,3\% adalah laki-laki. Pengguna internet mencapai 202,6 juta orang pada bulan Januari 2021. Disamping itu, jumlah pengguna internet mobile yaitu 195,3 juta, dan dari jumlah ini 96\% adalah pengguna internet dengan menggunakan perangkat smartphone.

\section{Metode}

Penelitian ini memberikan gambaran yang bersifat deskriptif terhadap kondisi dan situasi yang dihadapi oleh masyarakat, khususnya ibu-ibu arisan RT 01, terkait dengan penggunaan internet pada smartphone dalam bisnis online.

Metode yang digunakan dalam kegiatan pengabdian ini adalah memberikan informasi melalui seminar kepada ibu - ibu anggota arisan sebagai anggota kelompok masyarakat di lingkungan RT.01/RW 06 Perumahan Delima Puri, Kelurahan Tabek Godang, Kecamatan Bina Widya/Tampan, Delima, Pekanbaru. Adapun jumlah ibu - ibu arisan yang hadir pada saat kegiatan adalah sebanyak 19 (sembilan belas) orang dari 33 (tiga puluh tiga) orang anggota. Namun demikian, saat ini, ada beberapa anggota yang tidak aktif, disebabkan salah satunya adalah karena munculnya virus covid 19.

Dalam pelaksaanaan seminar, Ibu-ibu anggota arisan diminta untuk mendengarkan presentasi materi dan dipersilahkan untuk bertanya kepada pembicara selama kegiatan berlangsung. Setelah penyampaian materi, ibu -bu juga diminta menyampaikan pendapat, pengalaman ataupun kesulitan yang mereka hadapi terkait penggunaan internet pada smartphone.

Indikator yang digunakan untuk mengukur variable penggunaan internet pada smartphone untuk mendukung jual beli online tersebut adalah pengetahuan ibu-ibu secara umum tentang smartphone, pengetahuan tentang internet, pemanfaatan internet, dan media sosial atau platform yang sering digunakan.

\section{Hasil dan Pembahasan}

Pelaksanaan pengabdian kepada masyarakat yang dilakukan di RT 01 RW 06 Kelurahan Tabek Godang, Kecamatan Binawidya dihadiri oleh ibu-ibu anggota arisan sebanyak 19 (sembilan belas) orang yang bertempat tinggal di Perumahan Delima Puri, Kota Pekanbaru. Ibu -ibu arisan tersebut umumnya adalah ibu rumah tangga yang waktunya seluruhnya digunakan untuk mengurus keluarga, dan sebahagian kecil adalah pensiunan pegawai, dan beberapa memiliki pekerjaan sampingan, seperti berjualan makanan dan kebutuhan sehari-hari. 
Kegiatan arisan di lingkungan RT 01 ini secara umum adalah kegiatan kumpul kumpul yang dimaksudkan untuk menjalin silaturrahmi antar tetanggga. Disamping itu, kegiatan ini juga dapat memberikan informasi kejadian yang terjadi di sekitar lingkungan perumahan, serta juga dimaksudkan untuk dapat mengumpulkan atau menyimpan uang arisan untuk mempermudah ibu-ibu dalam hal menabung untuk sesuatu keperluan yang mendesak ataupun menabung untuk keperluan di hari lain.

Diluar kegiatan tersebut di atas, terdapat beberapa kegiatan tambahan arisan sebelum menyebarnya COVID 19 yaitu mengundang pihak lain ataupun memperoleh kunjungan dari beberapa pihak yang ingin menyampaikan informasi terkait sebuah program ataupun yang ingin memperkenalkan produk di lingkungan rukun tetangga tersebut Namun, setelah menyebarnya penyakit yang disebabkan oleh virus tersebut, kegiatan-kegiatan seperti ini nyaris tidak ada, dikarenakan adanya kekhawatiran penularan dan pelarangan untuk berkumpul bersama.

Namun demikian, terkait dengan terlaksananya kegiatan ini disebakan salah satu penulis adalah anggota arisan di lingkungan Rukun Tetangga 01, sehingga lebih kurang memahami situasi di lingkungan tersebut sehingga diizinkan untuk melakukan kegiatan pengabdian masyarakat setelah melakukan diskusi dengan pengurus kegiatan. Kegiatan ini dilakukan dengan memperhatikan protokol kesehatan, sehingga memungkinkan kegiatan ini terlaksana dengan baik.

Adapun kegiatan yang telah dilaksanakan adalah presentasi 2 (dua) materi yang terkait dengan penggunaan ataupun pengenalan internet pada smatphone, yakni: 1). Pemanfaatan internet pada smartphone untuk mendukung kegiatan bisnis online, 2). Pengenalan istilah -istilah internet dalam Bahasa Inggris pada sistem jual beli online.

Terkait dengan materi pertama, materi berisi tentang pengenalan mengenai handphone atau smartphone, mulai dari fungsinya selain dari alat komunikasi atau menelepon, juga dapat digunakan untuk berusaha secara online. Penjelasan mengenai penjualan secara online dan offline sampai kepada digital marketing yang memiliki keuntungan dengan jangkauan konsumen yang luas dan dapat dilakukan 24 (dua puluh empat) jam.

Penggunaan internet ini dalam usaha jual beli online disampaikan dengan memberikan contoh riil dalam kehidupan sehari-hari yang dapat diterima dan difahami oleh ibu -ibu anggota arisan. Contohnya berupa penjualan tas atau baju, makanan atau barang-barang kecil yang mudah didapatkan dan dengan harga yang layak jual. 


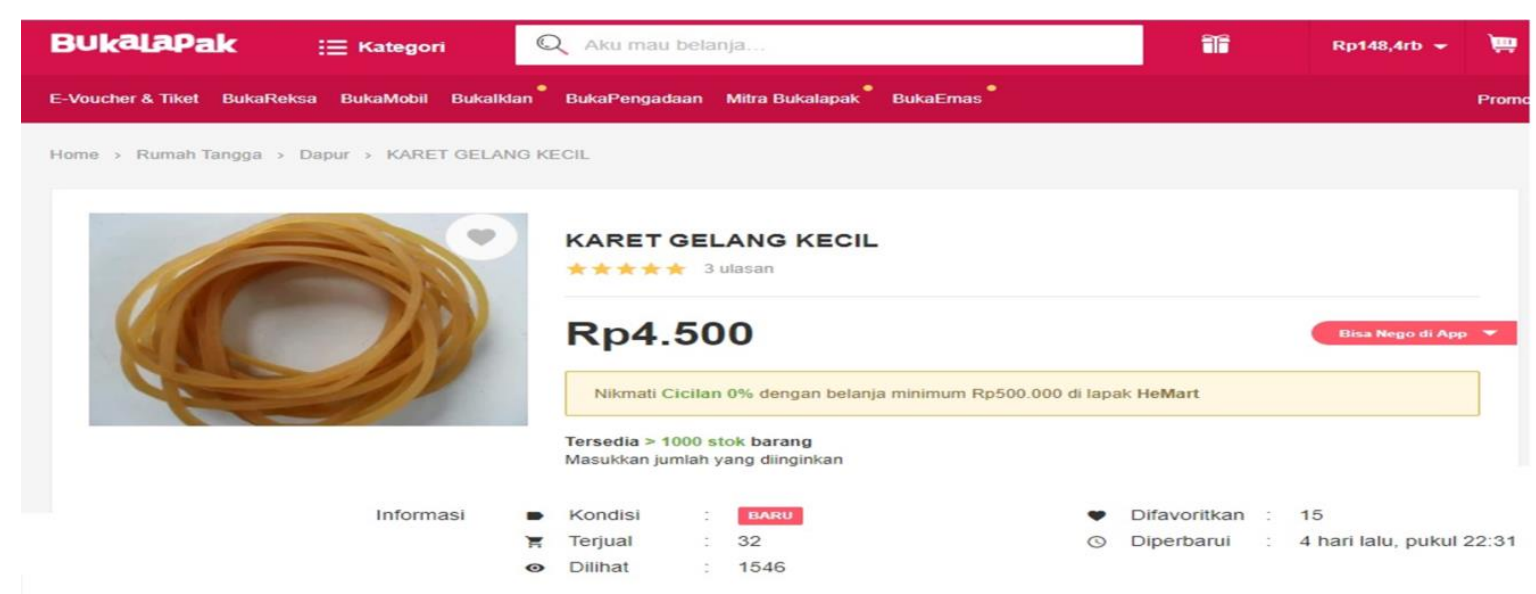

Gambar 1. Contoh produk yang dijual online pada salah satu toko online di internet.

Untuk memudahkan memahami bagaimana penggunaan internet ini juga dijelaskan jenis-jenis platform yang digunakan, baik itu instragram, faceboook, whatsapp, dan lain sebagainya. Berdasarkan survei yang dilakukan oleh Hotsuite.com pada tahun 2019 bahwa platform yang paling banyak digunakan di Indonesia secara berurutan adalah youtube, whatsapp, facebook dan instagram. Sementara itu, info yang diperoleh di kegiatan diskusi dengan ibu -ibu anggota arisan, jenis media yang banyak digunakan secara berurutan adalah whatsApp, facebook dan instragram.

Tabel 1. Jumlah anggota arisan yang menggunakan jenis platform

\begin{tabular}{|c|c|c|c|}
\hline \multicolumn{4}{|c|}{ Jenis Platform } \\
\hline $\begin{array}{c}\text { WhatsApp } \\
\text { (orang) }\end{array}$ & $\begin{array}{c}\text { Facebook } \\
\text { (orang) }\end{array}$ & Instagram (orang) & Tidak ada \\
\hline 9 & 5 & 3 & 2 \\
\hline
\end{tabular}

Sementara itu, ibu-ibu angoota arisan mayoritas memiliki handphone android, dan hanya sebahagian kecil menggunakan handphone biasa yang digunakan hanya untuk komunikasi telepon biasa. Penyebab lain tidak memiliki handphone android adalah karena tidak memerlukannya dan tidak tahu menggunakan handphone android. Hal ini kemungkinan terkait dengan usia dari pengguna yang sudah melebihi 50 tahun, yang menggunakan handphone hanya untuk komunikasi telepon saja.

Setelah menjelaskan materi pertama, kemudian diskusi dilakukan dengan tanya jawab sekitar jual beli online dengan menggunakan platform yang digunakan oleh ibu ibu tersebut. Secara umum, berdasarkan pertanyaan dan tanggapan yang disampaikan, kesulitan yang dihadapi oleh anggota arisan dalam memahami jual beli online sudah sangat baik, demikian juga dalam hal penggunaan WhatsApp sebagai media untuk memasarkan produk. Hal in bisa dikarenakan mereka tinggal di daerah kota pekanbaru, dimana arus informasi lebih cepat diterima, terutama dari anak-anak mereka yang masih muda yang memang seperti kita ketahui sangat menggemari perangkat ini. 
Pada dasarnya, beberapa dari mereka menggunakan whatsapp (termasuk whatsApp group arisan) sebagai media untuk berkomunikasi dengan teman, hiburan dan menjual produk secara online.

Adapun jenis produk yang mereka jual biasanya adalah makanan seperti kue, lauk pauk, keripik; kemudian pakaian, kebutuhan sehari-hari seperti telur, beras; hiasan bunga, dsb. Namun dengan hanya menggunakan whatsapp group, penjualan ini menjadi sangat terbatas pada kelompok kecil saja, sehingga jumlah pembeli juga sangat terbatas.

Pada umumnya, terutama ibu-ibu yang hadir yang masih berusia di bawah 50 (lima puluh) tahun, merasa perlu untuk memiliki sebuah usaha yang bisa dipasarkan dengan jaringan yang lebih luas.

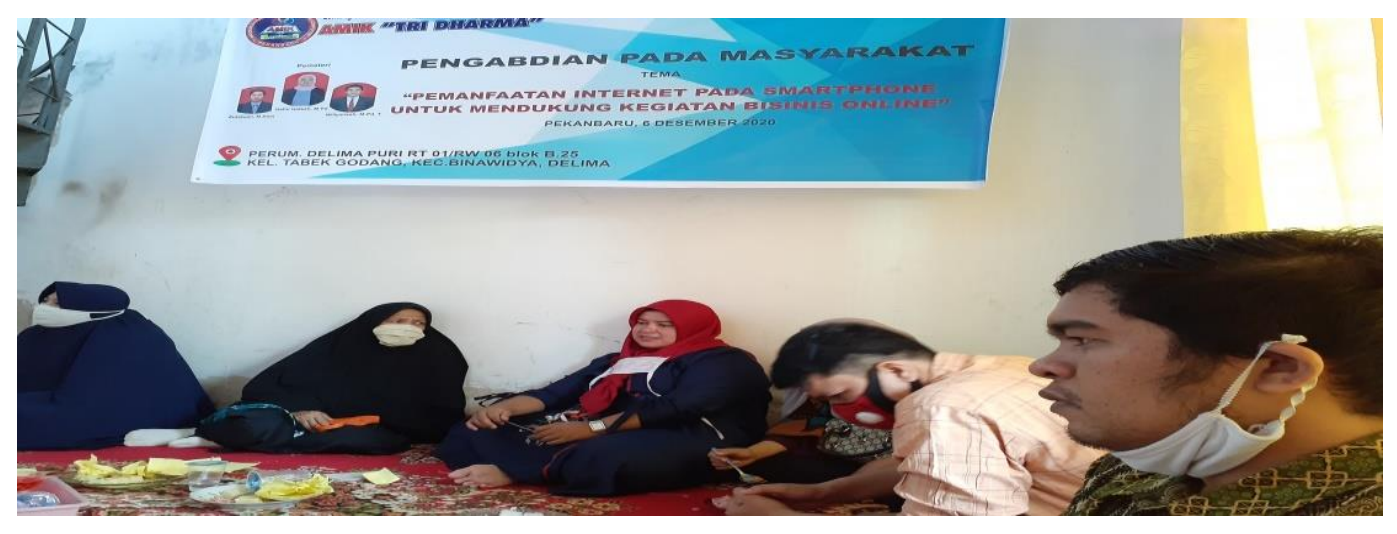

Gambar 1. Dokumentasi Foto Kegiatan

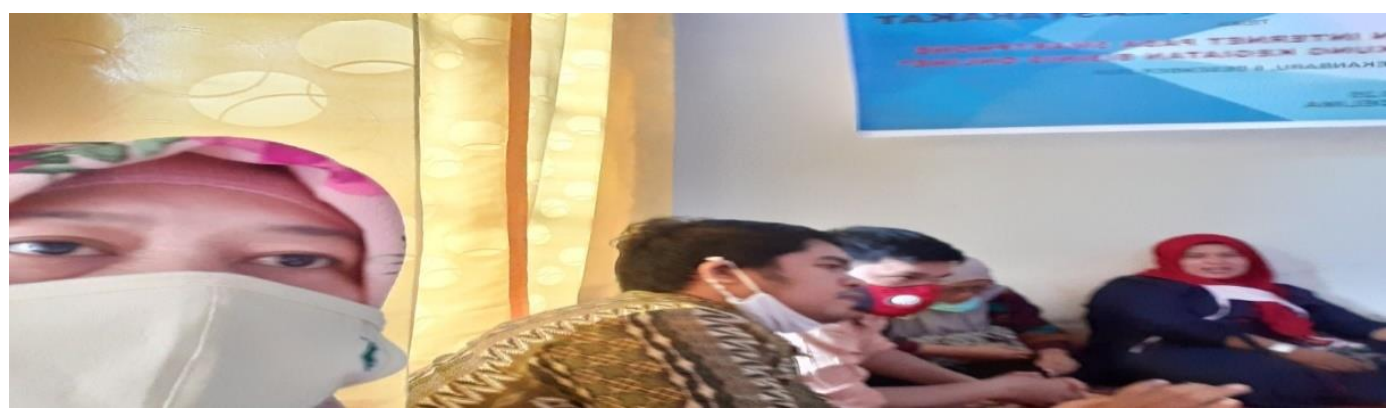

Gambar 2. Dokumentas Foto Kegiatan

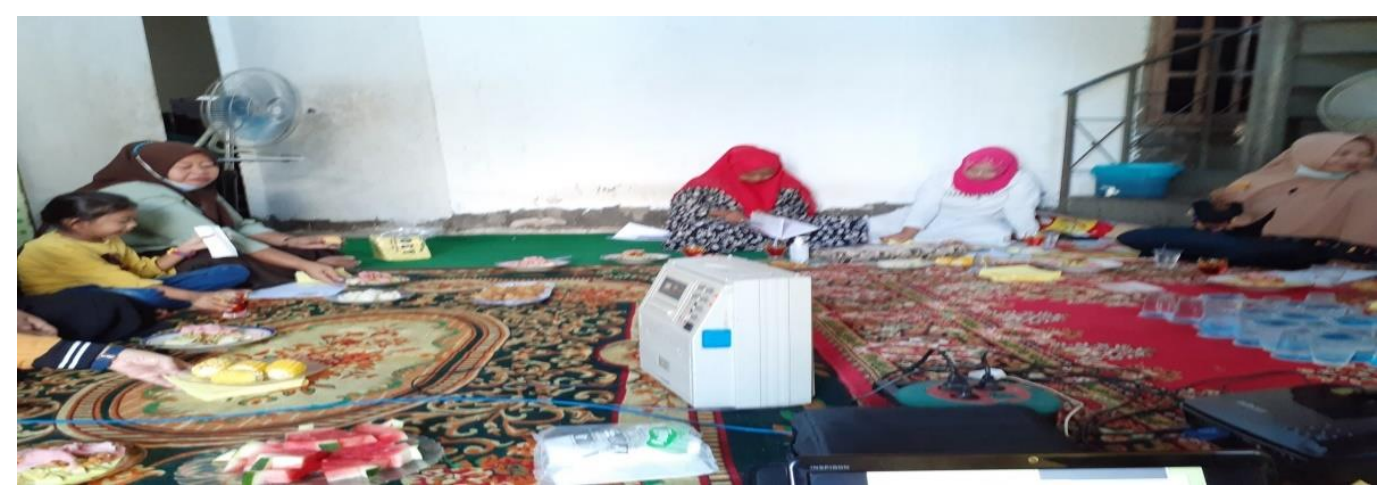

Gambar 3. Dokumentas Foto Kegiatan 


\section{Kesimpulan}

Kegiatan ini dimaksudkan untuk berbagi ilmu tentang pemanfaatan internet melalui pemanfaatan smartphone untuk mendukung kegiatan usaha online dan mengenalkan istilah-istilah Bahasa Inggris yang umum digunakan dalam hal jual beli online melalui internet. Selain hal tersebut, seminar ini juga dapat mengisi kegiatan arisan ibu-ibu RT disamping kegiatan pertemuan rutin yang mereka lakukan, yang diharapkan dapat meningkatkan pemahaman mereka dalam hal pemanfaatan internet.

Pemahaman ibu-ibu anggota arisan lingkungan RT 01 mengenai penggunaan fitur internet baik untuk berkomunikasi maupun untuk berusaha online, sebahagian besar sudah bagus, terutama ibu-ibu yang berusia dibawah 50 tahun. Demikian juga halnya pemahaman umum istilah jual beli online dalam Bahasa Inggris.

Keinginan dari beberapa ibu - ibu arisan tersebut adalah agar bisa memasarkan produk nya dengan jangkauan yang lebih luas Kesulitan yang seringkali dihadapi adalah terkait dengan biaya dan waktu dalam menggunakan internet dalam bisnis online.

Apabila teknologi internet dimanfaatkan dengan tepat maka akan memberikan manfaat yang lebih besar yaitu terbukanya kesempatan bagi industri rumah tangga untuk memperluas pasar penjualan barang/produk/jasa melalui pemanfaatan internet sehingga dapat membantu pendapatan keluarga, terutama di saat terjadinya penyebaran covid 19 .

\section{Ucapan Terima Kasih}

Penulis mengucapkan terima kasih kepada Ketua dan Pengurus Kegiatan serta anggota arisan RT 01 RW 06 Perumahan Delima Puri. Terima kasih juga disampaikan kepada Dosen Amik Tri Dharma Pekanbaru yang telah membantu terlaksananya kegiatan Pengabdian Kepada Masyarakat ini sampai kepada penulisan artikel yang diselesaikan dengan baik.

\section{Daftar Pustaka}

Ardila Djunu. (2016). Pemanfaatan Fitur Internet Pada Smartphone Oleh Masyarakat. $\mathrm{V}(5), 3$.

Fauzia, I. Y. (2016). Dalam Bisnis Di Kalangan Wirausahawan Perempuan. Stie Perbanas Press, 237-256. Https://Doi.Org/10.14414/Jbb.V5i2.544

Hermana, B., Farida, \& Adrianti, R. (2007). Model Adopsi Internet Pada Kaum Ibu: Pengembangan Dan Pengujian Instrumen Penelitian. Seminar Nasional Teknologi, 2007(November), 1-11.

Joesyiana, K. (2019). Penggunaan Media Online Shop Dalam Bisnis Pada Wirausaha Wanita (Studi Kasus Pada Pebisnis Wanita Komunitas Shalihah Preneur Melalui Pengelolaan Informasi Dengan Media Sosial). Jurnal Valuta, 5(2), 65-80.

Lestari, R. B. (2013). Pemberdayaan Wanita Melalui Teknologi Informasi. Finance \& Accounting, 2(2), 60-71. 